\title{
Association between GNRHR, LHR and IGF1 polymorphisms and timing of puberty in male Angus cattle
}

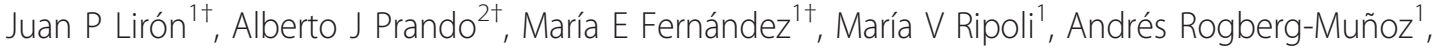 \\ Daniel E Goszczynski', Diego M Posik ${ }^{1,3}$, Pilar Peral-García ${ }^{1}$, Andrés Baldo ${ }^{2}$ and Guillermo Giovambattista ${ }^{{ }^{*}}$
}

\begin{abstract}
Background: In bovines, there are significant differences within and among beef breeds in the time when bulls reach puberty. Although the timing of puberty is likely to be a multigenic trait, previous studies indicate that there may also be single genes that exert major effects on the timing of puberty within the general population. Despite its economic importance, there are not many SNPs or genetic markers associated with the age of puberty in male cattle. In the present work, we selected three candidate genes, GNRHR, LHR and IGFI, and associated their polymorphisms with the age of puberty in Angus male cattle.

Results: After weaning, 276 Angus males were measured every month for weight (W), scrotal circumference (SC), sperm concentration (C) and percentage of motility (M). A total of 4 SNPs, two within GNRHR, one in LHR and one in IGF1 were genotyped using the pyrosequencing technique. IGF1-SnaBI SNP was significant associated $(P<0.01)$ with age at SC $28 \mathrm{~cm}$, but it were not associated with age at M 10\% and C 50 million. Genotype CC exhibited an average age at SC $28 \mathrm{~cm}$ of 7 and 11 days higher than $C T(p=0.037)$ and $\Pi(p=0.012)$, respectively. This SNP explained $1.5 \%$ of the genetic variance of age of puberty at SC28. LHR-1499L, GNRHR-SNP5 and GNRHR-SNP6 were not associated with any of the measurements. However, GNRHR haplotypes showed a suggestive association with age at SC $28 \mathrm{~cm}$.
\end{abstract}

Conclusions: The findings presented here could support the hypothesis that IGFI is a regulator of the arrival to puberty in male calves and is involved in the events that precede and initiate puberty in bull calves. Given that most studies in cattle, as well as in other mammals, were done in female, the present results are the first evidence of markers associated with age at puberty in male cattle.

Keywords: Gonadotropin releasing hormone receptor, Luteinizing hormone receptor, Insulin-like growth factor 1 , Bovine, Polymorphism, Male puberty

\section{Background}

Among cattle breeds, significant differences have been reported in the age when bulls reach puberty [1-5]. Although the timing of puberty is likely to be a multigenic trait, data from human and mouse indicate that there could be single genes with major effects involved. Despite its economic importance, there are few genetic markers associated with this trait. Recently,

\footnotetext{
* Correspondence: ggiovam@fcv.unlp.edu.ar

† Contributed equally

'Instituto de Genética Veterinaria (IGEVET), CCT La Plata - CONICET - Facultad de Ciencias Veterinarias, Universidad Nacional de La Plata, La Plata, Argentina Full list of author information is available at the end of the article
}

gonadotropin-releasing hormone receptor (GNRHR) polymorphisms have been associated with the days to first service after calving in dairy cattle [6], and with age of first corpus luteum in Brahman and Tropical Composite female [7]. Recently, Fortes et al. [8,9], using a system biology approach in Brahman and Tropical Composite dams, identified candidate genes and pathways (e.g. axon guidance, cell adhesion, ErbB signaling, and glutamate activity) that are known to affect pulsatile release of GNRH. However, these still remain to be investigated in bovine males. This reinforces the importance of identifying genes that regulate puberty and

\section{Biomed Central}


polymorphisms that explain these differences in bulls. To date, it is known that some male traits, such as scrotal circumference at 12 months and IGF1 serum concentration at 6 months, may be correlated with early female reproductive performance, measured as age at first corpus luteum. These results suggest that selection toward early puberty males would indirectly reduce the timing of puberty in their female relatives http://www. bifconference.com/bif2011/documents/GenPredJohnston.pdf and http://www.beefcrc.com.au/, accession date: $02 / 09 / 12$ ). This correlation would indicate that there are common genes involve in the development of puberty in both sexes.

GNRH and its receptor play a major role in coordinating sexual differentiation and reproduction in mammals, mediating the secretion of gonadotropic luteinizing hormone ( $\mathrm{LH}$ ) and follicle stimulating hormone (FSH). These hormones regulate gonadal function, including steroid hormone synthesis and gametogenesis. Genetic variations within GNRHR contribute to the regulation of pubertal timing in human and mouse [10]. In mammals, insulin like growth factor 1 (IGF1) has been identified as a signal controlling reproductive function, with possible links to somatic growth, particularly during puberty [11]. This factor has direct actions on GNRH neurons, and influence testicular growth, determining the development of seminiferous tubules and Leydig cells [12]. Furthermore, positive correlations were also found between serum concentrations of IGF1 and serum LH and testicular LH receptor (LHR) concentrations in bull calves [12]. Consequently, IGF1 could be considered a strong candidate gene for the regulation of testicular growth in the bull calf during pre-pubertal period. In the present work, we selected three candidate genes GNRHR, LHR and IGF1, to associate their polymorphisms with the age of puberty in male cattle; and we reported the first evidence of a marker associated with age at puberty in male cattle.

\section{Results and discussion}

All alleles were present within both herds, with minimum allele frequency and expected heterozygosity higher than 0.10 and 0.179 , respectively. A total of fifteen (ten within population and five for the entire sample) Hardy-Weinberg equilibrium tests were performed. With the exception of GNRHR haplotypes in Herd 1 and the combined population, none of these tests exhibited significant deviations from theoretical proportions $(\mathrm{P}>0.05)$ (Additional file 1: Table S1). These results evidenced that all the studied SNPs were suitable for association.

In bovine, several QTLs related to reproductive traits have been detected using microsatellites, some of which were associated with age at puberty http://www.
animalgenome.org/cgi-bin/QTLdb/BT/search. Most reported studies have used simpler indirect measurements (e.g. scrotal circumference, calculated age at puberty, age at first insemination) $[5,6,13,14]$. Recently, SNPs have been associated with timing of puberty in females $[6-9,13]$, but to date, they still remain unknown in males.

In the present work, we report the first evidence of markers associated with age at puberty in male cattle. Significant associations were detected between IGF1SnaBI SNP and age at SC $28 \mathrm{~cm}(\mathrm{p}<0.05)$, but it were not associated with age at M $10 \%$ and C 50 million. Genotype $C C$ exhibited an average age at SC $28 \mathrm{~cm}$ of 7 and 11 days higher than $C T(\mathrm{p}=0.037)$ and $T T(\mathrm{p}=$ 0.012 ), respectively. This SNP explained $1.5 \%$ of the genetic variance of age of puberty at SC28. LHR-I499L, GNRHR-SNP5 and GNRHR-SNP6 were not associated with any of the measurements. However, GNRHR haplotypes showed a suggestive association with age at SC 28 $\mathrm{cm}$ (Table 1). A resume of average phenotypic data was detailed in Additional file: Table S2.

Even though GNRH, $L H$ and its receptors play a major role in coordinating sexual differentiation and reproduction in mammals, and there are strong evidences that genetic variation within these genes contributes to the regulation of pubertal timing in human and mouse populations [15], the present study showed no effect of GNRHR and LHR SNPs on analyzed puberty traits. Our results are in agreement with a previous work [13] that also did not find correlations between early puberty in Nelore females and mutations in the LHR and GNRHR genes. Nevertheless, other polymorphisms in linkage disequilibrium within these genes could be associated with the analyzed traits. Further studies are necessary to evaluate the influence of GNRHR and $L H R$ variations in the events that precede and initiate puberty in bull calves, as well as testis growth and gametogenesis.

Physiological and gene expression data showed that IGF1 is involved in the events that precede and initiate puberty in bull calves. Recent evidence showed that IGF1 can regulate the hypothalamic-pituitary-gonadal axis via direct actions at the pituitary and gonadal levels of this axis [11]. In this sense, pre-pubertal IGF-1 serum concentrations have been genetically correlated with adult scrotal circumference and sperm motility, in bulls; and with the age at first calf and calving rate, in females [16]. In mammals, IGF1 has been identified as a regulator of testicular growth, influencing the development of the seminiferous tubules and Leydig cells [12]. Positive correlations were also found between serum concentrations of IGF1 and LH and testicular LHR concentrations in bull calves. Moreover, the IGF1-SnaBI has been demonstrated to influence IGF1 gene expression and IGF1 blood level in cattle [17]. In addition, IGF1 up- 
Table 1 Average estimated puberty age and standard error (SE) in days, for the genotypes of the SNPs LHR-I499L and IGF1-SnaBI, and the haplotypes of GNRHR; and the P-val for the genotype effect in the model are presented for the two criterions for age of puberty are showed: i) estimated at Scrotal Circumference $=28 \mathrm{~cm}$, ii) estimated at Sperm Motility $=10 \%$ and Sperm Concentration $=50$ million

\begin{tabular}{|c|c|c|c|c|c|c|}
\hline \multirow[t]{2}{*}{ Marker } & \multirow[t]{2}{*}{ Genotypes } & \multirow[t]{2}{*}{$\mathbf{N}$} & \multicolumn{2}{|c|}{ Age at SC28 } & \multicolumn{2}{|c|}{ Age at $510^{7} / 10 \%$ mot } \\
\hline & & & Genotype effect P-val & Age $\pm S E$ & Genotype effect P-val & Age $\pm S E$ \\
\hline \multirow[t]{3}{*}{ LHR-1499L } & AA & 17 & 0.456 & $292.27 \pm 6.84$ & 0.301 & $288.73 \pm 11.04$ \\
\hline & $A C$ & 94 & & $284.87 \pm 4.21$ & & $287.87 \pm 6.89$ \\
\hline & $\mathrm{CC}$ & 165 & & $287.28 \pm 3.71$ & & $279.96 \pm 6.12$ \\
\hline \multirow[t]{3}{*}{ |GF1-SnaB| } & CC & 84 & 0.027 & $294.27 \pm 4.58 \mathbf{A}$ & 0.354 & $287.55 \pm 7.59$ \\
\hline & $\mathrm{CT}$ & 142 & & $287.17 \pm 4.28 \mathbf{B}$ & & $281.02 \pm 6.95$ \\
\hline & $\Pi \mathrm{T}$ & 50 & & $282.98 \pm 4.94 \mathbf{B}$ & & $287.98 \pm 8.06$ \\
\hline \multirow[t]{9}{*}{ GNRHR haplotypes } & GC/GC & 22 & 0.271 & $300.15 \pm 5.90 \mathbf{a}$ & 0.124 & $291.82 \pm 9.63$ \\
\hline & GC/GT & 43 & & $296.75 \pm 4.32 \mathbf{a}$ & & $288.27 \pm 7.09$ \\
\hline & GC/AC & 12 & & $293.00 \pm 7.65$ & & $277.96 \pm 12.69$ \\
\hline & GC/AT & 78 & & $289.79 \pm 3.60$ & & $288.50 \pm 6.11$ \\
\hline & GT/GT & 15 & & $290.43 \pm 6.79$ & & $262.15 \pm 11.09$ \\
\hline & GT/AT & 53 & & $289.93 \pm 3.68$ & & $291.98 \pm 6.30$ \\
\hline & $A C / A C$ & 2 & & $271.02 \pm 23.69$ & & $322.16 \pm 36.18$ \\
\hline & AC/AT & 5 & & $270.23 \pm 10.71 \mathbf{b}$ & & $256.41 \pm 16.80$ \\
\hline & AT/AT & 47 & & $291.97 \pm 4.04$ & & $290.42 \pm 6.99$ \\
\hline
\end{tabular}

Different Bold Capital letters denote significant association $(p<0.05)$ between means. Different bold lower letters denote suggestive association $(p<0.1)$ between means. Bonferroni's means adjustment was performed for multiple comparisons

regulates $L H R$ and testosterone secretion in Leydig cells, and it has been shown to have an additive effect of LH and IGF1 on testicular cells number. Furthermore, IGF1 influences GNRH neurons during puberty through its receptor (IGF1R). For these reasons, IGF1 has been considered a strong candidate gene for the regulation of testicular growth in the bull calf during pre-pubertal period [11].

Regarding this, IGF1-SnaBI SNP was reported to affect animal weight at different ages in cattle [18-21]. However, in bovine and human, puberty has been associated more with stature or BMI than with weight [22,23]. Nevertheless, the effect of weight (estimated W at 300 days) was included as covariate in the used association statistical model. Considering the correlation between these traits, a permissive effect of IGF1on reproductive development, rather than a direct effect as discussed above, could explain the observed association between this SNP and estimated age at SC28 [24]. Regardless of the involved effect (direct or permissive), this findings support the hypothesis that IGF1-SnaBI SNP could be a useful predictor of early age of puberty.

\section{Conclusions}

The findings presented here could support the hypothesis that IGF1 is a regulator of the arrival to puberty in male calves and is involved in the events that precede and initiate puberty in bull calves. Given that most studies in cattle, as well as in other mammals, were done in female, the present results are the first evidence of markers associated with age at puberty in male cattle.

\section{Methods}

\section{Sample collection}

The study was performed on 276 Angus males belonging to two herds located in Buenos Aires Province (Argentine). Calves, sired by 24 bulls, were born in 2008 and 2009 winters, between July and September. After weaning and during the whole experiment, animals were pasture fed. Every month, animals were weighed (W) and scrotal circumference measured (SC). When first bull calves reached $26 \mathrm{~cm}$ of $\mathrm{SC}$, sperm concentration $(\mathrm{C})$ and percentage of motility $(\mathrm{M})$ were added to the monthly measurements for the next three months. These monthly SC, $\mathrm{C}$ and $\mathrm{M}$ measurements were similar to those made by Lunstra and Cundiff [4], and are adequate to get the meaningful changes during the peri-pubertal development.

The present research was carried out following the internationally recognized guidelines, and the experimental design was approved by the "Comité Institucional para el Cuidado y Uso de los Animales de Laboratorio" (Faculty of Veterinary Sciences, National University of La Plata, Argentina; Res N 129/09).

\section{Scrotal circumference and sperm quality measurements}

Scrotal circumference (SC) was measured with a flexible measuring tape at the greatest horizontal distance 
around the scrotum after manually forcing the testicles into the base of the scrotum, as described by Kealey et al [25]. Semen samples were collected by electroejaculation. Sperm concentration (C) were measured using a photometer SPERMACUE 12300/0500 (Minitube, Tiefenbach, Germany), while percentage of progressive motility $(\mathrm{M})$ were calculated by duplicate estimates on semen diluted in phosphate buffered saline ( $\mathrm{pH} 7.4)$, using a microscope $(\times 400$ magnification) equipped with a stage warmer $\left(37^{\circ} \mathrm{C}\right)[26]$.

\section{DNA extraction and pyrosequencing genotyping}

DNA was extracted from blood samples using Wizard Genomic kit following manufacturer instructions (Promega, Madison, WI, USA). Herein, we selected four polymorphisms located into three candidate genes: two SNPs in GNRHR and one in IGF1 that were previously reported by Lirón et al. [27] and Ge et al. [18], respectively. The GNRHR-SNP5 and GNRHR-SNP6 were chosen because a previous study showed that these SNPs were sufficient to tag the four more frequent GNRHR haplotypes present in the studied Angus populations [27]. The IGF1-SnaBI SNP, located in the promoter region, was selected because TESS (Transcription Element Search System; http://www.cbil.upenn.edu/cgi-bin/ tess/tess?RQ=WELCOME) analysis showed that it colocalizes with the NF1 transcription factor binding site [17]. LHR-I499L corresponds to a novel SNP detected in the studied Angus populations by re-sequencing analysis of $L H R$ exon 11. This exon was analyzed because it codifies for a transmembrane region of the protein, a critical domain for the receptor function. Despite this SNP has not been associated yet with the age of puberty in male cattle, it has been reported that mutations on this region of LHR can cause sexual precocity in humans, which justifies the search of polymorphisms in this exon [28].

Four pyrosequencing assays were developed to genotype GNRHR-SNP5 [19], GNRHR-SNP6, LHR-I499L, and IGF1-SnaBI SNPs. First, PCR was carried out for each gene in a total volume of $50 \mu \mathrm{l}$, containing $20 \mathrm{mM}$ Tris$\mathrm{HCl}(\mathrm{pH}=8.4), 50 \mathrm{mM} \mathrm{KCl}, 2.5 \mathrm{mM} \mathrm{MgCl} 2,100 \mathrm{mM}$ of each dNTP, $0.75 \mathrm{U}$ Taq polymerase (Metabion, Martinsried, Germany), $0.1 \mathrm{mM}$ of each primer, and $50 \mathrm{ng}$ of DNA. One of the primers (forward or reverse) in each reaction was biotinilated to allow the purification in the next step (Additional file 1: Table S3 and Additional file 1: Table S4). Cycling conditions were: 45 cycles of $45 \mathrm{sec}$ at $94^{\circ} \mathrm{C}, 45 \mathrm{sec}$ at 56,58 and $60^{\circ} \mathrm{C}$ for GNRHR-SNP6, LHR-I499L, and IGF1-SnaBI respectively, and $45 \mathrm{sec}$ at $72^{\circ} \mathrm{C}$, with a final elongation step of $7 \mathrm{~min}$ at $72^{\circ} \mathrm{C}$. Biotinilated amplified products were purified by streptavidin-coated Sepharose beads capture to be used as pyrosequencing template. Pyrosequencing reaction was performed with $0.3 \mu \mathrm{M}$ internal sequencing primer
(Additional file 1: Table S4) and PyroMark Gold Q96 reagents (Qiagen, Hilden, Germany), and run on a PSQ96MA. Outgoing results were analyzed using pyrosequencing software (Biotage AB, Uppsala, Sweden).

\section{Genetic variability measurements}

Allele frequencies, unbiased expected heterozygosity (he) and Hardy-Weinberg equilibrium (HWE) for each SNP within each herd and for the whole sample were estimated using exact test implemented in GENEPOP 4 [29] and ARLEQUIN 3.5 [30] softwares. Phases were reconstructed with the Bayesian statistical method implemented in Phase v2.1.1 [31,32] using default options, except that the program was run five times and the last iteration was 10 times longer, as suggested by the authors. Phases were considered reliable when $\mathrm{P}$ value estimated by Phase was higher than 0.8 .

\section{Association between genetic markers and age at puberty}

In male cattle, puberty is defined as the time when each ejaculation has at least $50 \cdot 10^{6}$ sperm cells and a $10 \%$ of linear motility [1]. In females, it is defined as the age at which the first corpus luteum is observed [33]. Routinely, in commercial farms, a bull is considered to arrive at puberty when its $\mathrm{SC}$ reaches to $28 \mathrm{~cm}$. This trait has a high correlation with age at puberty [4]. For this reason, to perform the association analysis, SNPs and GNRHR haplotypes were tested against two estimated puberty ages. The first one considers the age when bulls reach $28 \mathrm{~cm}$ of $\mathrm{SC}$, while the second one consider puberty age when $\mathrm{M}$ is $10 \%$ and $\mathrm{C}$ is 50 million. For the three measurements, the regression was performed with the following logistic equation using the NLIN procedure implemented into SAS 9.0 software (SAS Inst. Inc.) [34]:

$$
\mathrm{y}=\mathrm{A} /\left[1+\mathrm{b} \mathrm{e}^{(-\mathrm{kt})}\right]
$$

$\mathrm{y}=$ measured traits (SC, M or C), $\mathrm{t}=\mathrm{age}, \mathrm{A}, \mathrm{b}$ and $\mathrm{k}$ $=$ parameters calculated for each individual from raw data. Furthermore, weight at 300 days was estimated with the following Gompertz equation using NLIN procedure implemented into SAS 9.0 software (SAS Inst. Inc.) [34]:

$$
y=A e^{[-b e(-k t)]}
$$

The following general model was used to analyze the association between puberty traits and genotypes:

$$
\mathrm{Y}_{\mathrm{ijkl} l}=\mu+\mathrm{S}_{\mathrm{i}}+\mathrm{G}_{\mathrm{j}}+\mathrm{B}_{\mathrm{k}}+\mathrm{O}_{\mathrm{l}}+\beta\left(\mathrm{x}_{\mathrm{ijk} \mathrm{k}}-\mathrm{x}\right)+\mathrm{e}_{\mathrm{ijk}},
$$

where $Y_{\mathrm{ijkl}}=$ phenotypic observation, $\mu=$ the overall mean, $S_{i}=$ the fixed effect of $i^{\text {th }}$ year, $G_{j}=$ the fixed effect of $j^{\text {th }}$ genotype, $B_{k}=$ the fixed effect of $k^{\text {th }}$ herd, $\mathrm{O}_{\mathrm{l}}=$ random effect of $\mathrm{l}^{\text {th }}$ sire, $\beta\left(\mathrm{x}_{\mathrm{ijk \textrm {k }}} \mathrm{-} \mathrm{x}\right)=$ regression on body weight at 300 days and $\mathrm{e}_{\mathrm{ijk}}=$ random error. The 
model used did not include a pedigree matrix because when the available pedigree data was considered, the fit estimation parameter (BIC) clearly increases. The statistical analyses were carried out utilizing MIXED procedure implemented into SAS 9.0 (SAS Inst. Inc.). Animals with missing data (field or genotype) were excluded from each analysis. For statistically significant $(\mathrm{p}<0.05)$ and suggestive $(\mathrm{p}<0.1)$ main effects, least squares means were reported and Bonferroni's means separation test was used to determine differences between genotypes. The percentage of the genetic variance accounted by the i-th SNP was computed according to Falconer and Markey [35].

\section{Additional material}

Additional file 1: Table S1. Gene frequency, Hardy-Weinberg

equilibrium (HWE), expected heterozygosities $\left(h_{e}\right)$, and gene

differentiation estimated for GNRHR-SNP5, GNRHR-SNP6, LHR-1499L and IGF1-SnaBI alleles identified by pyrosequencing analysis within each herd and in the whole sample. Table S2. Average estimated puberty age and weigh estimated at 300 days (W 300), with their standard errors (SE) calculated for each herd and year. Results for the two criterions for age of puberty are: i) estimated at Scrotal Circumference (SC) $=28 \mathrm{~cm}$, ii) estimated at Sperm Motility $(M)=10 \%$ and Sperm Concentration $(C)=$ 50 million. Table S3. Summary information of genotyped SNPs for gonadotropin-releasing hormone receptor (GNRHR). luteinizing hormone receptor (LHR) and insulin-like growth factor 1 (IGF1) genes. Table S4. Primer sequences and annealing temperatures used for SNP genotyping by pyrosequencing assays.

\section{Acknowledgements}

Research for this paper was supported by ANPCYT, CONICET, CICBA and UNLP. We are grateful to Flores Chicas de Areco and La Trinidad de Pertino studs for experimental collaborations and Dr. Martín de Narbaitz for his support in sperm measurements.

\section{Author details}

'Instituto de Genética Veterinaria (IGEVET), CCT La Plata - CONICET - Facultad de Ciencias Veterinarias, Universidad Nacional de La Plata, La Plata, Argentina. ${ }^{2}$ Departamento de Producción Animal, Facultad de Ciencias Veterinarias, Universidad Nacional de La Plata, La Plata, Argentina. ${ }^{3}$ Comisión de Investigaciones Científicas de la Provincia de Buenos Aires, Buenos Aires, Argentina.

\section{Authors' contributions}

$J P L, A J P, A B, G G$ conceptualized and supervised the whole study. AJP, AB and GG collected the phenotypic data. MEF, MVR, DEG and DMP performed DNA sequencing and SNP genotyping. JPL, ARM and GG analyzed the data. $J P L, A R M, M E F, P P G$ and GG drafted the manuscript together. All authors read and approved the final manuscript.

\section{Competing interests}

The authors declare that they have no competing interests.

Received: 18 October 2011 Accepted: 5 April 2012

Published: 5 April 2012

\section{References}

1. Wolf FR, Almquist JO, Hale EB: Pubertal behaviour and pubertal characteristics of beef bulls on high nutrition allowance. J Anim Sci 1965, 24:761-765.
2. Evans ACO, Davis FJ, Nasser LF, Bowman P, Rawlings NC: Differences in early patterns of gonadotropin secretion between early and late maturing bulls and changes in semen characteristics at puberty. Theriogenology 1995, 43:569-578.

3. Chase CC, Chenoweth PJ, Larsen RE, Hammond AC, Olson TA, West RL, Johnson DD: Growth, puberty, and carcase characteristics of Brahman-, Senepol-, and Tuli sired $F_{1}$ Angus bulls. J Anim Sci 2001, 79:2006-2015.

4. Lunstra DD, Cundiff LV: Hereford- and Angus-sired F1 bulls Growth and pubertal development in Brahman-, Boran-, Tuli-, Belgian Blue-, Hereford- and Angus-sired F1 bulls. J Anim Sci 2003, 81:1414-1426.

5. Casas E, Lunstra DD, Cundiff LV, Ford JJ: Growth and pubertal development of F1 bulls from Hereford, Angus, Norwegian Red, Swedish Red and White, Friesian, and Wagyu sires. J Anim Sci 2007, 85:2904-2909.

6. Derecka K, Ahmad S, Hodgman TC, Hastings N, Royal MD, Woolliams JA, Flint APF: Sequence variants in the bovine gonadotrophin releasing hormone receptor gene and their associations with fertility. Anim Genet 2010, 41:329-331.

7. Fortes MRS, Li Y, Collis E, Zhang Y, Hawken RJ: IGF1R: a Candidate Gene for Cattle Puberty. Proceeding of the 32nd Conference of the International Society for Animal Genetics: 26-30 July 2010; Edinburgh, Scotland International Society of Animal Genetics; 2010, 92.

8. Fortes MR, Reverter A, Zhang Y, Collis E, Nagaraj SH, Jonsson NN, Prayaga KC, Barris W, Hawken RJ: Association weight matrix for the genetic dissection of puberty in beef cattle. Proc Natl Acad Sci USA 2010, 107(31):13642-13647.

9. Fortes MR, Reverter A, Nagaraj SH, Zhang Y, Jonsson NN, Barris W, Lehnert S, Boe-Hansen GB, Hawken RJ: A single nucleotide polymorphismderived regulatory gene network underlying puberty in 2 tropical breeds of beef cattle. J Anim Sci 2011, 89(6):1669-1683.

10. Ferreira Gontijo Silveira L, Barbosa Trarbach E, Latronico AC: Genetics basis for GnRH-dependent pubertal disorders in humans. Mol Cell Endocrinol 2010, 324:30-38.

11. Daftary SS, Gore AC: IGF-1 in the brain as a regulator of reproductive neuroendocrine function. Exp Biol Med 2005, 230:292-306.

12. Bagu ET, Davies KL, Epp T, Arteaga A, Barrett DM, Duggavathi R, Barth A, Rawlings NC: The Effect of Parity of the Dam on Sexual Maturation, Serum Concentrations of Metabolic Hormones and the Response to Luteinizing Hormone Releasing Hormone in Bull Calves. Reprod Domest Anim 2010, 45(5):803-810.

13. Milazzotto MP, Rahal P, Nichi M, Miranda-Neto T, Teixeira LA, Ferraz JBS, Eler JP, Campagnari F, Garcia JF: New molecular variants of hypothalamus-pituitary-gonad axis genes and their association with early puberty phenotype in Bos taurus indicus (Nellore). Livest Sci 2008, 114:274-279.

14. Morris CA, Pitchford WS, Cullen NG, Esmailizadeh AK, Hickey SM, Hyndman D, Dodds KG, Afolayan RA, Crawford AM: Quantitative trait loci for live animal and carcass composition traits in Jersey and Limousin back-cross cattle finished on pasture or feedlot. Anim Genet 2009, 40(5):648-654.

15. Ascoli M, Fanelli F, Sagaloff DL: The Lutropin/Choriogonadotropin Receptor, A 2002 Perspective. Endocr Rev 2002, 23:141-174.

16. Yilmaz A, Davis ME, Simmen RCM: Estimation of (co)variance components for reproductive traits in Angus beef cattle divergently selected for blood serum IGF-I concentration. J Anim Sci 2004, 82:2285-2292.

17. Maj A, Snochowski M, Siadkowska E, Rowinska B, Lisowski P, RobakowskaHyzorek D, Oprzadek J, Grochowska R, Kochman K, Zwierzchowski L: Polymorphism in genes of growth hormone receptor (GHR) and insulinlike growth factor-1 (IGF1) and its association with both the IGF1 expression in liver and its level in blood in Polish Holstein-Friesian cattle. Neuro Endocrinol Lett 2008, 29:981-989.

18. Ge W, Davis ME, Hines HC, Irvin KM, Simmen RC: Association of a genetic marker with blood serum insulin-like growth factor-I concentration and growth traits in Angus cattle. J Anim Sci 2001, 79:1757-1762.

19. Li C, Basarab J, Snelling WM, Benkel B, Murdoch B, Hansen C, Moore SS: Assessment of Positional Candidate Genes myf5 and igf1 for Growth on Bovine Chromosome 5 in Commercial Lines of Bos tauru. J Anim Sci 2004, 82:1-7.

20. Siadkowska E, Zwierzchowski L, Oprzadek J, Strzalkowska N, Bagnicka E, Krzyżewski J: Effect of polymorphism in IGF-1 gene on production traits in Polish Holstein-Friesian cattle. Anim Sci Pap Rep 2006, 24:225-237. 
21. De la Rosa Reyna XF, Montoya HM, Castrellón W, Rincón AMS, Bracamonte MP, Vera WA: Polymorphisms in the IGF1 gene and their effect on growth traits in Mexican beef cattle. Genet Mol Res 2010, 9(2):875-883.

22. Smith BA, Brinks JS, Richardson GV: Relationships of Sire Scrotal Circumference to Offspring Reproduction and Growth. J Anim Sci 1989, 67:2881-2885

23. Elks CE, Perry JRB, Sulem $P$, Chasman DI, Franceschini $N$, et al: Thirty new loci for age at menarche identified by a meta-analysis of genome-wide association studies. Nat Genet 2010, 42(12):1077-1085.

24. Burns BM, Gazzola C, Holroyd RG, Crisp J, McGowan MR: Male Reproductive Traits and Their Relationship to Reproductive Traits in Their Female Progeny: A Systematic Review. Reprod Dom Anim, doi: 10.1111/j.1439-0531.2011.01748.x.

25. Kealey CG, MacNeil MD, Tess MW, Geary TW, Bellows RA: Genetic parameter estimates for scrotal circumference and semen characteristics of Line 1 Hereford bulls. J Anim Sci 2006, 84:283-290.

26. Lunstra DD, Echternkamp SE: Puberty in beef bulls: acrosome morphology and semen quality in bulls of different breeds. J Anim Sci 1982, 55:638-648.

27. Lirón JP, Prando A, Ripoli MV, Rogberg-Muñoz A, Posik DM, Baldo A, PeralGarcía P, Giovambattista G: Characterization and validation of bovine Gonadotropin releasing hormone receptor (GnRHr) polymorphisms. Res Vet Sci 2010, PubMed PMID: 21030057.

28. Thenmen AP, Huhtaniemi IL: Mutations of Gonadotropins and Gonadotropin Receptors: Elucidating the Physiology and Pathophysiology of Pituitary-Gonadal Function. Endocrine Rev 2000, 21(5):551-583.

29. Rousset F: GENEPOP'007, a complete reimplementation of the GENEPOP software for Windows and Linux. Mol Ecol Resour 2007, 8:103-106.

30. Excoffier L, Lischer HEL: Arlequin suite ver 3.5: A new series of programs to perform population genetics analyses under Linux and Windows. Mol Ecol Resour 2010, 10:564-567.

31. Li N, Stephens M: Modeling linkage disequilibrium, and identifying recombination hotspots using SNP data. Genetics 2003, 165:2213-2233.

32. Crawford DT, Bhangale N, Li G, Hellenthal M, Rieder D, Nickerson DA, Stephens M: Evidence for substantial finne-scale variation in recombination rates across the human genome. Nat Genet 2004, 36:700-706.

33. Johnston DJ, Barwick SA, Corbet NJ, Fordyce G, Holroyd RG, Williams PJ, Burrow HM: Genetics of heifer puberty in two tropical beef genotypes in northern Australia and associations with heifer and steer-production traits. Anim Prod Sci 2009, 49:399-412.

34. Quirino CR, Vale Filho VR, Andrade VJ, Pereira JCC: Evaluation of four mathematical functions to describe scrotal circumference maturation in Nelore bulls. Theriogenology 1999, 52:25-34.

35. Falconer DS, Mackay TFC: Introduction to Quantitative Genetics Harlow Essex, England: Addison Wesley Longman Limited; 1996.

doi:10.1186/1471-2156-13-26

Cite this article as: Lirón et al:: Association between GNRHR, LHR and IGF1 polymorphisms and timing of puberty in male Angus cattle. BMC Genetics 2012 13:26.

\section{Submit your next manuscript to BioMed Central and take full advantage of:}

- Convenient online submission

- Thorough peer review

- No space constraints or color figure charges

- Immediate publication on acceptance

- Inclusion in PubMed, CAS, Scopus and Google Scholar

- Research which is freely available for redistribution

Submit your manuscript at www.biomedcentral.com/submit
CioMed Central 